\title{
FEASIBILITY STUDY FOR THE APPLICABILITY OF APPLYING THE HOT RECYCLING TECHNOLOGY FOR REPAIR OF ASPHALT CONCRETE PAVEMENTS
}

\author{
Vyacheslav Savenko, \\ Doctor of Technical Sciences, Professor, Head of Department \\ Department of Transport Construction and Property Management \\ National Transport University, Kyiv, Ukraine, \\ ORCID ID: https://orcid.org/0000-0001-8174-7728 \\ Sergii Illiash, \\ Head of department of normative and engineering of roadworks \\ M.P. Shulgin State Road Research Institute State Enterprise - Derzhdor NDI SE \\ Kyiv, Ukraine, \\ ORCID ID: https://orcid.org/0000-0002-3001-8012 \\ Tetiana Stasiuk, \\ Junior researcher of department of normative and engineering of roadworks \\ M.P. Shulgin State Road Research Institute State Enterprise - Derzhdor NDI SE \\ Kyiv, Ukraine, \\ ORCID ID: https://orcid.org/0000-0001-5921-4503
}

DOI: https://doi.org/10.31435/rsglobal_ws/31052020/7070

\section{ARTICLE INFO}

Received: 18 March 2020

Accepted: 10 May 2020

Published: 31 May 2020

\section{KEYWORDS}

highway,

asphalt concrete pavement, technical and economic comparison, recycling,

asphalt concrete,

current repair,

operational maintenance,

economic efficiency.

\begin{abstract}
The main technological solutions for the current repair of non-rigid pavement in Ukraine are identified. The cost assessment of repair technologies was carried out depending on the cost of arrangement of the pavement and its maintenance. The technical and economic comparison of traditional technologies of current repair of asphalt concrete pavement and technologies of hot regeneration of asphalt concrete is carried out. An expert method and a method of comparison were used in the research. To calculate the comparative economic efficiency, the indicator of reduced costs was taken into account with the risk-free discount rate. Estimate calculations were performed using the software CMETA_8_Online. Based on the analysis of the obtained results, it is established when comparing only the cost of repairs, the most cost-effective methods of renovating the riding qualities of roads are surface treatment and hot recycling technology by the Reshape method. Technologies of hot regeneration of asphalt concrete and arrangement of wear layers from cast emulsion and mineral mixes are cost-effective when carrying out the comparison for interrepair (5 years for current average repair) period.
\end{abstract}

Citation: Vyacheslav Savenko, Sergii Illiash, Tetiana Stasiuk. (2020) Feasibility Study for the Applicability of Applying the Hot Recycling Technology for Repair of Asphalt Concrete Pavements. World Science. 5(57), Vol.1. doi: 10.31435/rsglobal_ws/31052020/7070

Copyright: (C) 2020 Vyacheslav Savenko, Sergii Illiash, Tetiana Stasiuk. This is an open-access article distributed under the terms of the Creative Commons Attribution License (CC BY). The use, distribution or reproduction in other forums is permitted, provided the original author(s) or licensor are credited and that the original publication in this journal is cited, in accordance with accepted academic practice. No use, distribution or reproduction is permitted which does not comply with these terms.

Introduction. Taking management decisions during the implementation of new equipment, materials and technologies should be based on the results of their feasibility study. Feasibility study of design decisions involves two aspects of analysis: technical and economic. The technical aspect involves the development of a number of options that is possible in terms of their technical implementation. The economic aspect involves an economic evaluation of each of the options [1]. 
An important component of the strategy for the development and maintenance of the road network in Ukraine is measures to prevent the destruction of the road pavement which includes current repair.

Traditional technological solutions for the current repair of non-rigid pavement in Ukraine mainly include additional arrangement of pavement wearing courses: asphalt concrete layers, crushed stone-mastic layers, wearing courses of cast emulsion and mineral mixtures [1]. Fulfillment of such works allows renovating the riding qualities of the road but requires significant funds and reserve of road construction materials. Taking into account the tendency of increasing the cost on road construction materials, in particular on imported bitumen, the technology of their reuse is relevant.

One of the promising methods of renovating the riding quality of roads is the technology of hot regeneration of asphalt concrete based on the reuse of materials. Depending on the method of preparation, there is a technology of preparation of hot regenerated asphalt mixtures at the plant and directly on site. According to the world practice of road construction, technologies of hot recycling of paving asphalt concrete on site are classified depending on the type and purpose of work, manufacturing processes and application of regenerated mixtures as follows [2]:

- Reshape method - profiling;

- Repave method - profiling with the renovation of a wearing course;

- Remix method -regeneration with a change in the composition of the old asphalt concrete by adding new materials in the amount of up to $30 \%$ by weight;

- Remix Plus method -regeneration with a change in the composition of old asphalt concrete and simultaneous arrangement of a layer of new asphalt concrete mix in one passage.

Studies described in [3-6] have shown that by the use of hot recycling technologies on site an economic effect from $20 \%$ to $35 \%$ compared to traditional technologies of repairing asphalt pavements can be achieved. However, the authors of these works determined the economic effect without taking into account the costs on operation of the repaired areas which are very important factors.

Taking into account a fairly wide range of works on current repairs in Ukraine and insufficiently studied technology of hot regeneration of asphalt concrete, it is important to conduct a technical and economic comparison for choosing a rational option.

The object of research is the technology of current repair of asphalt pavement.

The purpose of the study is to evaluate the cost-effectiveness of technologies for hot regeneration of asphalt concrete in comparison with alternative technologies for repairing asphalt pavement.

The methodology of the study.

The efficiency of different repair technologies was determined by comparing the reduced costs per $1000 \mathrm{~m}^{2}$ of road pavement consisting of the cost of repairs, the cost of materials, costs on operational maintenance during the comparative period (T). As a criterion for assessing the comparative efficiency of technology the minimum value of the integrated costs $C_{i}$ which also includes the loss of road users during repairs was used [7].

The calculation of the reduced costs is carried out taking into account the risk-free discount rate $E$.

To compare the costs of different repair technologies the following formula was used [7]:

$$
C_{i}=\sum_{i=1}^{n}\left[\left(C_{m r} \times(1+E)^{t}\right) \times n\right]+\sum_{i=1}^{m}\left[\left(C_{c m r_{-} o m} \times(1+E)^{t}\right) \times m\right]+\sum L_{r u}^{r} \times(1+E)^{t}
$$

where $C_{m r}-$ the cost on current midterm repairs of pavement;

$n$ - the number of current midterm repairs that are performed during the comparative period $T$;

$C_{\text {cmr_om }}$ - costs for current minor repairs and operational maintenance of pavement;

$L_{r u}^{r}-$ losses of road users during repair works.

$m$ - the number of years of operational maintenance of road pavement by the selected option of work performance;

$E$ - risk-free discount rate in relative units;

$(1+E)$ - cost discount rate;

$t$ - year of calculation. 
The costs of repair and operational maintenance work were determined by the resource method in accordance with SOU 42.1-37641918-085: 2018 "Highways. Rules for determining the cost of current repair and operational maintenance.

The direct costs were determined on the basis of resource estimate norms DSTU B D.2.2-27: 2016 "Resource element estimate norms for construction works. Highways (Collection 27)", DSTU B D.2.7-1: 2012 "Resource estimate norms of operation of construction machines and mechanisms", SOU 42.1-37641918-034: 2018 "Road machines and mechanisms. Resource estimate norms of operation of construction machines and mechanisms", SOU 42.1-37641918-035: 2018 "Roads. Resource element estimate norms for repair and construction works".

There are no resource element estimate norms for works on hot recycling of road asphalt concrete on site by Reshape and Repave methods. Taking into account the above, individual estimate norms were developed for the relevant works, taking into account the requirements of DSTU-N B D.1.1-6: 2013 "Guidelines for the development of resource element estimate norms for construction works".

For normalization the needs in labor and technical resources during the development of individual estimate norms, the calculation and research method was used [8]. It is based on the use of data obtained as a result of carrying out the special regulatory research (measurements, photo-timing).

Determination of the value of labor costs $\left(V_{l c}\right)$ of construction workers is calculated by the formula [8]:

$$
V_{l c}=\frac{A_{p c} * 100}{\left(100-\left(P C_{p_{-} f w}+P C_{r_{-} p n}+P C_{m}\right)\right) * 60}
$$

where $A_{p c}$ - the amount of projected costs for the process meter, man-min;

$P C_{p_{-} f w}-$ projected costs for preparatory and final work, $\%$;

$P C_{r_{-} p n}$ - projected costs for recreation and personal needs, \%;

$P C_{m}$ - projected costs for maintenance of machines and mechanisms.

The time of use of machines and mechanisms ( $T_{m}$, mach.h) and labor costs of units servicing machines and mechanisms $\left(L C_{u s m}\right.$, man.h) were determined on the basis of the current standard working time of construction workers and the number of performers:

$$
\begin{gathered}
T_{m}=V_{l c}: N_{w} \\
L C_{u s m}=T_{m} \cdot N_{u s}
\end{gathered}
$$

where $N_{w}$ - quantitative composition of the construction workers, man.;

$N_{u s}$ - quantitative structure of the unit serving machines and mechanisms, man.

The scope and cost of certain types of work to be performed during the current minor repairs and operational maintenance of $1 \mathrm{~km}$ of public roads were determined taking into account the minimum maintenance standard according to [9].

During determining the cost of work on current minor repairs and operational maintenance, the conditions of operation of non-rigid pavement after repair work were taken into account. With this in mind, the following options for carrying out the current minor repairs and operational maintenance were selected [7]:

-the first option: without taking into account the work on the elimination of potholes after the repair of pavement;

-the second option: includes the whole complex of repair works. 
When formatting the minimum value of the integrated costs indicator, the losses of road users during repair works were neglected, as they are insignificant and will not significantly impact on the research results.

The comparative period $(\mathrm{T})$ is determined taking into account the inter repair time of road pavements operation for highways of category 3 in accordance with VBN G.1-218-050-2001 "Inter repair time of road pavements operation on public roads" and is 5 years.

\section{Research results and discussion.}

On the basis of the conducted analysis on the experience of application of the technologies of the current repair of the road pavement in Ukraine and of the expert assessment, the following main technologies of the current mid-term repair were chosen:

1) Milling and construction of a new layer of asphalt concrete. Including cold milling of asphalt concrete pavement by milling to a depth of $5 \mathrm{~cm}$, preparation of asphalt concrete mixture and its transportation to the object, arrangement of a top layer of $5 \mathrm{~cm}$ thickness with a fine-grained asphalt concrete mixture by paver;

2) Removal of potholes and arrangement of a new layer of asphalt concrete. Includes patching, preparation of the asphalt mixture, transporting the mixture to the site and arranging the top layer of $5 \mathrm{~cm}$;

3) Milling and arrangement of a reclaimed asphalt layer. Includes cold milling of asphalt concrete pavement to a depth of $5 \mathrm{~cm}$, transportation of milled crumbs to the asphalt plant, preparation of asphalt mixture using regeneration additives and its transportation to the site, arrangement of a top layer of $5 \mathrm{~cm}$ thickness with fine-grained regenerated asphalt mixture by paver;

4) Hot recycling technology using the Reshape method. Includes heating and milling the pavment to a depth of $2 \mathrm{~cm}$ using a remixer, mixing the milled material in the mixer, paving and compacting the mixture. On top of the reclaimed layer, a wearing course of $10 \mathrm{~mm}$ thickness of cast emulsion-mineral mixture is laid.

5) Hot recycling technology using the Repave method.

Includes heating and milling of pavement to a depth of $4 \mathrm{~cm}$ using a remixer, mixing the milled material with simultaneous placement of a wearing course of asphalt concrete mixture and compaction of two layers in one passage.

6) Hot recycling technology using the Remix method. The method includes heating and milling the surface to a depth of $3 \mathrm{~cm}$ using a remixer, mixing a milled material with the addition of new asphalt mixture and bitumen (up to 1\%), placement and compaction of the layer.

7) Hot recycling technology by the Remix Plus method. The method includes heating and milling of pavment to a depth of $5 \mathrm{~cm}$ using a remixer, mixing a milled material with the addition of bitumen (up to $1 \%$ ) with simultaneous placement of a layer of $3 \mathrm{~cm}$ thickness of asphalt mixture and compaction of two layers in one passage.

8) The technology of thin-layer pavement of cast emulsion-mineral mixtures. This technology includes the elimination of potholes in the asphalt pavement and arrangement of a wearing course of cast emulsion-mineral mixture in two passages by a specialized machine. The total thickness of the layer is $3 \mathrm{~cm}$.

9) Surface treatment. This technology includes the removal of potholes in the asphalt pavement and arrangement of a single surface treatment with spreading the crushed stone by a specialized machine.

Taking into account [10] determination of the cost of works for each of the selected technologies (Fig. 2), estimated calculations have been made with the use of the program complex SMETA_8_Online in current prices as of 15.04.2020.

According to [7], the annual costs of maintenance and current minor repairs of the national road of III category have been calculated. According to the first variant (without taking into account works on elimination of potholes of road pavement) expenses on $1000 \mathrm{~m}^{2}$ of pavement make 31500,00 $\mathrm{UAH}$, and for the second variant - 15011,63 UAH.

When estimating the costs, different terms of operation life cycle of road pavements repaired according to technologies 1-9 were also taken into account. An example of the calculation of costs for the current mid-term repair and operational maintenance of $1000 \mathrm{~m}^{2}$ of the highway of the III category repaired by technology 1 , is given in Table 1 . Costs by technology are similarly calculated. The total costs of the current mid-term repair and maintenance for each option are compared in Tables 2. 


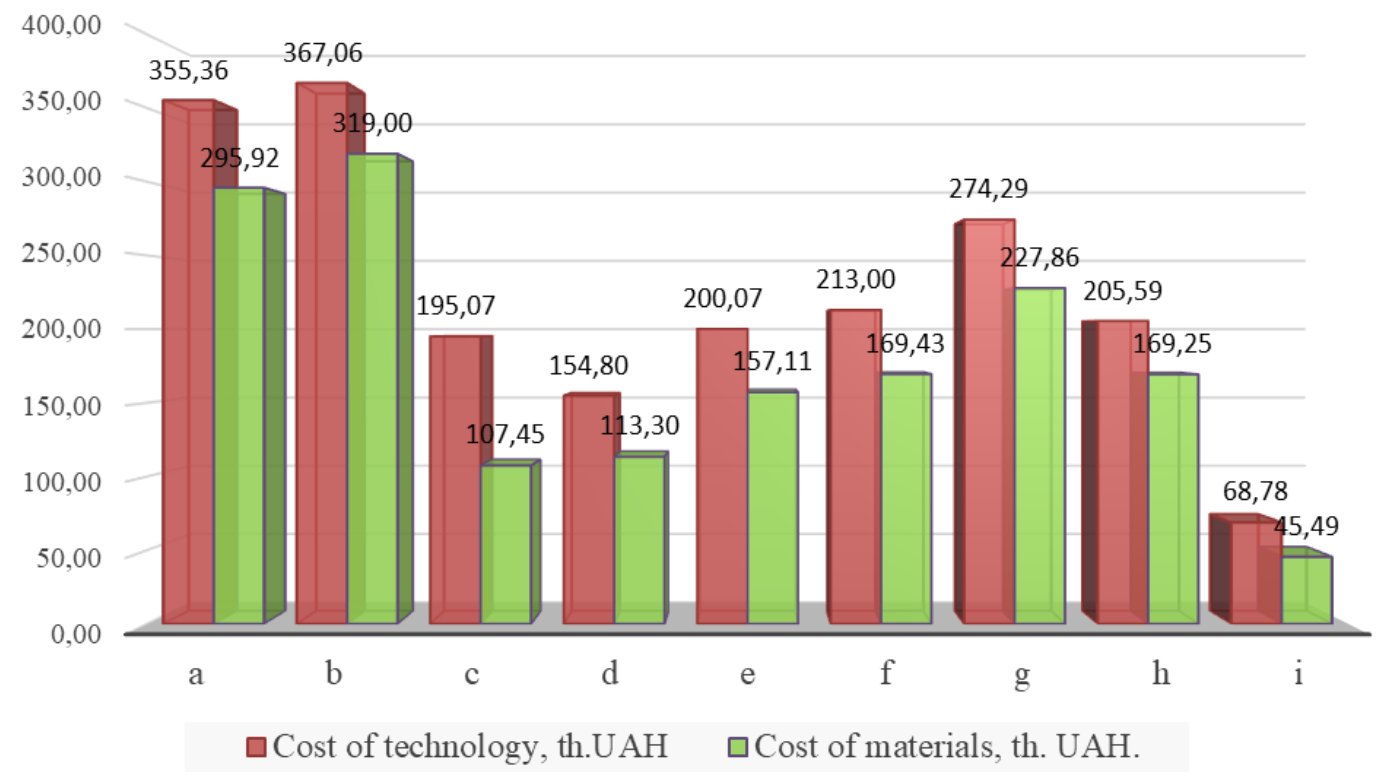

Fig. 1. Current repair cost of $1000 \mathrm{~m}^{2}$ of road pavement by technology: $a-1 ; b-2 ; c 3 ; d-4 ; e-5 ; f-6 ; g-7 ; h-8 ; i-9$

Table 1. Costs of current mid-term repair and maintenance of $1000 \mathrm{~m}^{2}$ of category III road repaired by technology 1

\begin{tabular}{|c|c|c|c|c|c|}
\hline \multirow{2}{*}{ Year } & Discount factor & $C_{m r}$ & $C_{c m r_{-} \text {om }}$ & Costs, thousand UAH & Annual costs, \\
\cline { 3 - 5 } & & 355,361 & - & 355,361 & $\begin{array}{c}\text { Accumulation } \\
\text { thousand UAH } \\
\text { thousts, } \\
\text { UAH }\end{array}$ \\
\hline 0 & 1 & - & 13,344 & 13,344 & 355,361 \\
\hline 1 & 1,05 & - & 14,011 & 14,011 & 382,705 \\
\hline 2 & 1,103 & - & 14,718 & 14,718 & 397,716 \\
\hline 3 & 1,158 & - & 15,452 & 15,452 & 412,886 \\
\hline 4 & 1,216 & - & 34,048 & 34,048 & 446,934 \\
\hline 5 & 1,276 & 355,361 & 124,523 & 446,934 & - \\
\hline Total & - & \multicolumn{2}{|r}{} \\
\hline
\end{tabular}

Table 2. Costs of current mid-term repair and maintenance of $1000 \mathrm{~m}^{2}$ of category III road repaired by technology 1-9.

\begin{tabular}{|c|c|c|c|c|c|c|c|c|c|}
\hline \multirow{2}{*}{ Year } & \multicolumn{8}{|c|}{ Annual costs by 3a technology $1-9$, thousand UAH } \\
\cline { 2 - 11 } & 1 & 2 & 3 & 4 & 5 & 6 & 7 & 8 & 9 \\
\hline 0 & 355,361 & 367,057 & 195,068 & 154,801 & 200,073 & 212,995 & 274,292 & 205,588 & 68,781 \\
\hline 1 & 13,344 & 13,344 & 13,344 & 13,344 & 13,344 & 13,344 & 13,344 & 13,344 & 28,000 \\
\hline 2 & 14,011 & 14,011 & 14,011 & 29,4 & 14,011 & 14,011 & 14,011 & 29,400 & 29,40 \\
\hline 3 & 14,718 & 14,718 & 30,884 & 30,884 & 30,884 & 30,884 & 14,718 & 30,884 & 30,884 \\
\hline 4 & 15,452 & 32,424 & 32,424 & 284,877 & 32,424 & 32,424 & 15,452 & 367,702 & 144,594 \\
\hline 5 & 34,048 & 34,048 & 34,048 & 16,226 & 34,048 & 34,048 & 34,048 & 16,226 & 34,048 \\
\hline Total & 446,934 & 475,602 & 319,779 & 529,532 & 324,784 & 337,706 & 365,865 & 663,144 & 335,707 \\
\hline
\end{tabular}

On the basis of the data from Tables 2, a graphic representation of the given costs for the current mid-term repair and maintenance of the road, depending on the service life of the road, is made (Fig. 2). 


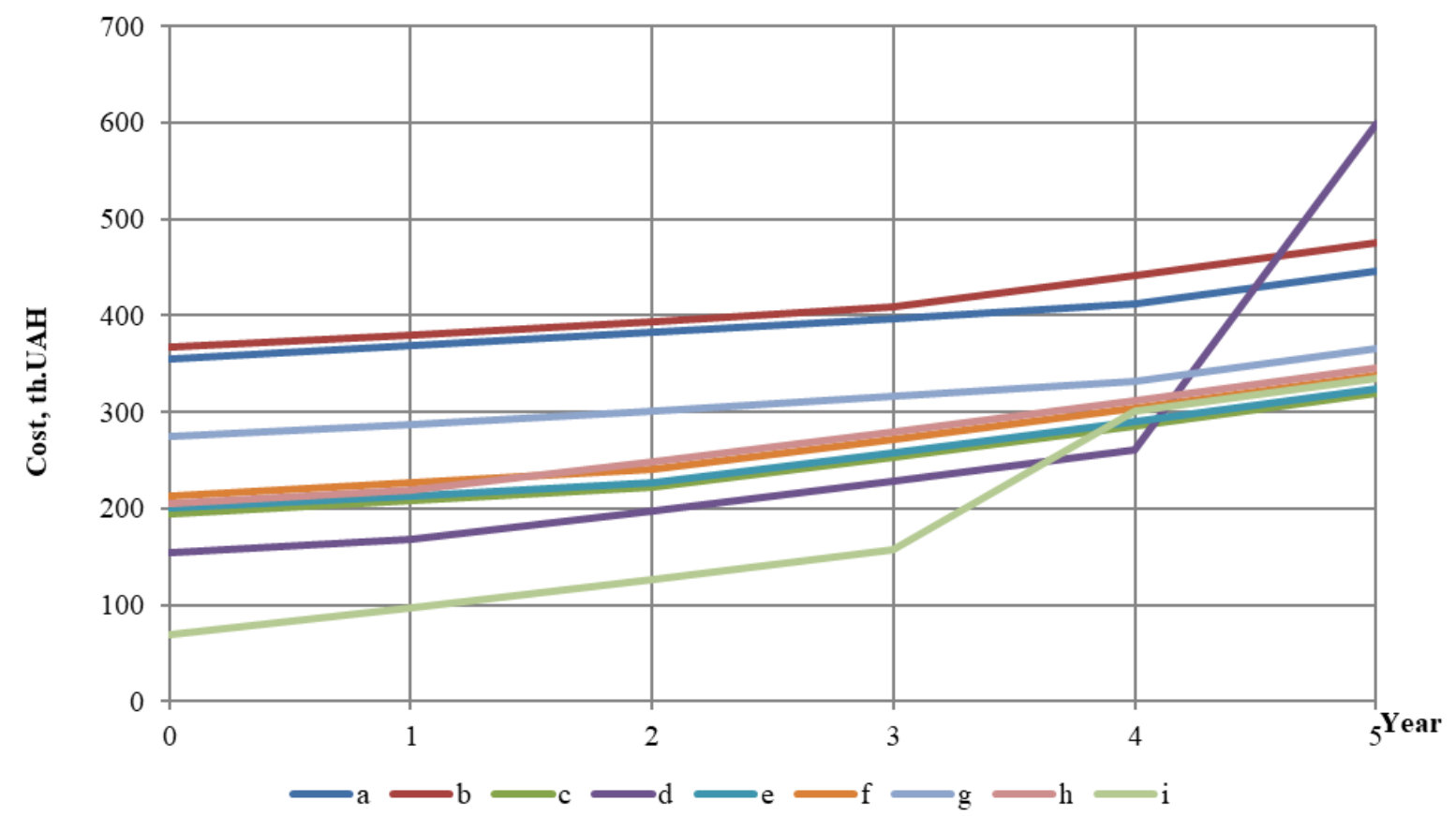

Fig. 2. Chart of annual reported costs for current mid-term road repair and maintenance, depending on repair technology:

$$
a-1 ; b-2 ; c 3 ; d-4 ; e-5 ; f-6 ; g-7 ; h-8 ; i-9
$$

Charts in Fig. 1 and Fig. 2 show that when comparing only the cost of repair, economically viable methods of restoring the riding qualities of roads is the surface treatment and hot recycling technology by Reshape method. However, the expert analysis and experience of application of such technologies show that the motor road repaired by the mentioned technologies requires the next current mid-term repair rather than the motor road repaired by alternative technologies. This, in turn, has also affected the minimum value of the integral cost indicator for a comparative period of 5 years.

The most expensive methods in estimating the minimum value of integral cost indicator for a comparative period of 5 years are "traditional" repair technologies with milling the old layer of the road pavement and arangement of a new layer, but at the same time, these technologies are the most qualitative and durable.

The technologies of hot regeneration of asphalt concrete and arrangement of wearing courses from cast emulsion-mineral mixtures have average cost of repair, but in the five-year perspective are the most economically advantageous.

Conclusions. It has been established that when comparing only the cost of repair, surface treatment and hot recycling technology using the Reshape method are economically viable methods of restoring the riding qualities of roads.

The technologies of hot recovery of asphalt concrete and arrangement of wearing courses from cast emulsion-mineral mixtures are economically advantageous when comparing them for the period between repairs ( 5 years for the current mid-term repair).

The cost of repair by any technology is too dependent on the cost of construction materials and the share of local materials at the facility, so in each case, when choosing a method of repair, it is necessary to conduct a pre-project technical and economic comparison.

\section{REFERENCES}

1. Гончаренко В.В., Нагайчук В.М., Катукова В.М., Клименко О.М., Ілляш С.І., Нормативне забезпечення влаштування захисних шарів зносу покриттів автомобільних доріг. Збірник «Дороги $\mathrm{i}$ мости. Київ, 2016. Вип. 16

2. Kandhal, P. Pavement Recycling Guidelines for State and Local Governments [Electronic resource] // P. Kandhal, R. Mallick. US Department of Transportation, Federal Highway Administration; Research, Development, and Technology. - Publ. № FHWA-SA-98-042. - 1997 - Retrieved from: http://www.fhwa.dot.gov 
3. Anderson, K.V. Long-Term Performance of a Hot In-Place Recycling Project - Final Report [Electronic resource] / K.V. Anderson, M. Russell, J.F. Uhlmeyer, et al. // Washington State Department of Transportation Research Report WA-RD 738. - 2016. - 99 p. - Retrieved from: http://www.fhwa.org

4. Hosokawa H. A case study of work done by a hot in-place recycling (HIR) Machines - [Electronic resource] / H. Hosokawa, A. Gomi, Y. Kanzaki, A. Kasahara // Retrieved from: http://www.greenarm.com/corporate/paper_db/HIR\%20for\%20ICPT.pdf

5. Wells M. Informed Infrastructure. The magazine for civil and structural engineers. -- [Electronic resource] /M. Wells// Retrieved from: https://informedinfrastructure.com/36026/hot-in-place-asphalt-recyclingyields-benefits-for-road-rehabilitation/

6. Stroup-Gardiner, M. Recycling and Reclamation of Asphalt Pavements Using In-Place Methods [Electronic resource] / M. Stroup-Gardiner, S.R. Godwin, J.M. Williams, et al. // NCHRP Synthesis 421, Transportation Research Board, Washington, D.C. - 2011. - 82 p. - Retrieved from: http://www.trb.org

7. МР В.2.3-03450778-847:2014 «Методичні рекомендації з техніко-економічного порівняння конструкцій дорожнього одягу різного типу»

8. МР В.2.3.2-218-03449261-468:2005 «Методичні рекомендації 3 проектування і перевірки розрахунково-аналітичним та розрахунково-дослідницьким методом технічно обгрунтованих норм часу на механізовані будівельні і ремонтно-будівельні роботи в дорожньому господарстві».

9. Методика визначення обсягу фінансування будівництва, реконструкції, ремонту та утримання автомобільних доріг, затверджена наказом Міністерства інфраструктури України, Міністерства фінансів України від 21 вересня 2012 року № 573/1019, зареєстрована в Міністерстві Юстиції України 16 жовтня 2012 року за № 1743/22046. Retrieved from: https://zakon.rada.gov.ua/laws/show/z1734-12/print

10. СОУ 42.1-37641918-085:2018 Автомобільні дороги. Правила визначення вартості робіт 3 поточного ремонту та експлуатаційного утримання 